\title{
Advocacy of Increasing Health Budget in The Parepare City
}

\author{
Kasman $^{1}$, Darmawansyah ${ }^{2}$, Alimin Maidin ${ }^{3}$, Amran Razak $^{4}$ \\ $\left\{\right.$ kasman_ternate@yahoo.com ${ }^{1}$, darmawangsyah@yahoo.com² ${ }^{2}$, aliminmaidin@gmail.com ${ }^{3}$, \\ amran.razak34@yahoo.co.id $\left.{ }^{4}\right\}$ \\ Health District Parepare City (Doctoral Program Hasanuddiin University), Jl. Titang No.10, Kec. \\ Soreang, Kota Parepare, Sulawesi Selatan 91132 Indonesia $^{1}$ \\ Health Economics Lecture in FKM Unhas, Jl. Perintis Kemerdekaan Indonesia ${ }^{2,3,4}$
}

\begin{abstract}
In decentralization, an advocacy is needed to increase the health budget in Parepare District. One of the advocacy methods recommended by the World Bank is the economic loss approach. This research is observational in the field of health economics that contributes directly to the magnitude of the economy lost of the community and the government and provides advocacy to the executive and legislative to see the harm it causes. The research results show the amount of direct cost, which consists of household expenditure for transport Rp.295,865,500. Indirect Cost of YLD of Rp.14.688.000, and YLL of Rp.28.986.336.00, so the amount of DALY is Rp.43.674.336.000. Total economic loss of Rp.43.970.201.500. These huge economic losses can be prevented by increasing the allocation of health budgets for promotive and preventive efforts and expanding the coverage of health insurance for the community. There is a need to advocate the executive and legislative about the importance of Guarantee on Public Health Financing by conducting studies in terms of economic losses so that all Strategic Alliances believe that health is an investment.
\end{abstract}

Keywords: Advocacy, Economic Lost, Health Insurance

\section{Introduction}

In the current era of decentralization, the health sector is intended to be able to advocate for all stakeholders in health planning and budgeting.

One way to advocate for health financing ßthat has been carried out and recommended by the World Bank is the economic loss approach if a health problem cannot be prevented and addressed early [1]. This approach provides a warning to all stakeholders, especially the executive and legislative that the economic losses caused by the disease are far greater than the Regional Original Revenue (PAD) [2],[3],[4]. So that it is expected that both the legislative and the executive give more serious attention to the health sector, which if not handled properly, can cause huge economic losses [5], [6].

\subsection{Economic Losses}

\section{Economic Losses from Poor Health Bad}

Health problems cause economic losses for both the population (households) and the government. The assumption that states that health is a consumptive thing is a wrong 
response. Health problems can cause huge economic losses which have rarely been counted clearly. The economic value of the loss, if calculated, is doubled compared to the regional income (PAD) [2], [3]. Such a large loss, although it cannot be eliminated at all, actually can be reduced, because in general the most common causes of health problems in Indonesia are preventable diseases. The problem is about infections that can be prevented through improving environmental sanitation, behavior change, and immunization. If an intervention can reduce the loss, then the cost of the intervention is also an investment. [8]

Conceptually there are short-term and long-term losses that can arise including: [4], [7],

1. Short-term losses include:

a. Loss of comfort and prosperity

b. Loss of opportunity for social interaction

c. Expenditures on health costs by residents

d. Loss of productive time due to illness and death

e. Expenditure on health costs by the government and companies.

f. Long-term losses:

g. Decreasing the quality of human resources (the lost generation)

h. Declining investor interest to enter an area that has many health problems (e.g. malaria, DHF, rabies, etc.)

Long-term losses are also difficult to calculate in monetary terms, which can be done is to estimate how many pregnant women and toddlers who experience various health and nutrition disorders [8]. Long-term losses can be in the form of health problems that occur in the early life of the population. Anemia of pregnant women, low birth weight, infection and malnutrition of toddlers is a potential problem that causes inhibition of growth and development of brain cells, which in turn will hinder the development of intelligence and human emotions [9]. This has a huge long-term impact, which is often referred to as the "lost generation" threat [10].

\subsection{Disability Adjusted Life Years (DALY)}

Within the next two decades, we will witness a dramatic change in the "Health Needs" of the world's population. Four-fifths of the world's population living in developing countries will be burdened with non-communicable diseases such as depression and heart disease, injuries, smoking-related diseases [11],[12]. These diseases will soon replace the position of infectious diseases and infections and malnutrition, which has been the main cause of disability and premature death [12].

By 2020 the above non-communicable diseases will increase and become the main cause of seven in ten deaths in developing countries (now less than five in 10 deaths) [13].

I was calculating losses due to "illness" by the World Bank and WHO in 1993 proposed a special concept to quantify the value of losses due to falling ill or dying at an age before reaching life expectancy. There were three terms put forward, namely Years of Life Lost (YLL), Years Lived With Disability (YLD) and Disability Used Life Years (DALY) [14].

Years of Life Lost (YLL) is the number of years lost because the population died before reaching an average lifespan or Life Expectancy (LE). So if LE is 63 years old and someone dies at the age of 23 , then YLL for that person is 40 years old. For several residents, the number of YLL can be calculated in one ye

YLL $=€ d(L E-t)$ 
Where "d" is the number of deaths due to an illness in the population, and "LE" is the life expectancy and " $\mathrm{t}$ " is the age at death. Ar, namely, by using the "life table" technique in this case [15], [16]:

Years lived with disability (YLD) is the number of years that are not productive because a person falls ill so that they cannot do daily activities (disabled). So, if someone in one year cannot be productive for 36 days due to falling ill, then that person's YLD is $36 / 365=0.1$ years. The amount of YLD can also be calculated for one particular population group for one year, that is, if it is known the prevalence of illness and the average non-productive days for the disease [17].

Disability Adjusted Life Years (DALY) is the number of YLL with YLD or: DALY = YLL + YLD. In the realization of the Millennium Development Goals (TPM), particularly in the health sector, efforts are made to finance programs, even though those that will produce economic benefits far outweigh the costs incurred. Millions of lives are saved from infectious diseases and malnutrition, which means increasing the number of life years saved also improves the quality of life by counting DALY. With effective health financing WHO estimates that US \$330 million of DALY will be saved for every 8 million preventable deaths. Assuming conservatively, that every DALY saved will produce economic benefits equivalent to one year of per capita income estimated at the US \$ 563 in 2015, the direct economic benefit of 330 million DALY is the US \$ 186 billion per year [18], [19].

The rescue of DALY will have implications for economic growth, because DALY that is saved will eliminate poverty traps that hinder economic growth, and this will add tens or even hundreds of billions of dollars a year through increasing per capita income [20], [21].

\section{Method}

\subsection{Economic Losses}

This study is observational research in the field of health economics that contributes directly to the magnitude of the economic losses of society and government due to illness and death and both. As well as providing advocacy to the government to see the losses it causes.

\subsection{Research time Time used in the study, from January to June 2018, using data on morbidity and mortality from January to December 2017. Rences}

\subsection{Research sites This research was carried out in the City of Parepare.}

\subsection{Methods of Collecting Data, Assumptions and Formula Economic Cost}

1. Secondary Data is taken from Hospitals, Health Offices, BPS and Bappeda, and other related institutions.

2. The assumptions and formulas used in calculating the number of economic costs in this study are:

a. Productive Age Percentage $=59.05 \%$ (BPS Parepare Regency, 2017)

b. The number of visits by Puskesmas patients for the 10 major diseases.

c. Using the Regional Minimum Salary (Upah Minimum Regional=UMR) $=\mathrm{Rp}$. 2.700,000/ Year 
d. Life Expectancy for Parepare City $=70,64$ years

e. The form used is:

1) Economic Loss due to YLD $=($ new + old case $) \times$ DD $\times \%$ PA $x$ DMS

2) Economic Loss due to $Y L L=d x(e x-X d) x \% P A \times 365$ days $x$ DMS

3) Total Economic Loss = Economic Value DALY + HH. Exp

Information:

YLD $=$ Years Lived with Disability (Number of years lost due to illness)

YLL $=$ Years of Life Lost (Number of years lost due to premature death)

DALY = Disability Adjusted Life Years (Number of years lost due to premature illness and death)

HH-Exp = Household Expenditure (Household expenditure specifically for health)

Gov-Exp = Government Expenditure (government spending specifically on health)

DMS = District Minimum Salary (District / City Minimum Wage)

$\mathrm{DD}=$ Disability Days

$\% \mathrm{PA}=\%$ Productive Age (productive age)

$\sum \mathrm{d}=$ Number of death (Number of deaths)

$\mathrm{Xd}=$ Age of death

ex $=$ Life Expectancy at each age

\subsection{Processing and Presentation of Data}

Data is processed and presented by calculating:

Losses due to illness consisting of household expenses (Household Expenditure) for modern medicine and traditional medicine,

Losses due to illness and premature death before reaching Life Expectancy.

Losses are due to both (Economic Lost due to Disability and Premature death).

The processed data is presented in the form of tables and narratives obtained from the search results of all costs incurred by the community and the costs of DALY.

\section{Results}

\subsection{Direct Cost}

Household Expenditure (HH-Exp) Treatment of Disease

Household Medicine Expenditure is the cost spent/ spent by households in obtaining health services, which consists of the cost of patient registration and the cost of medical treatment provided, as well as services that must be paid by the patient, plus transportation costs needed in the health center (Puskesmas=PKM).

The biggest cost incurred by the household is outside the transportation costs (Household Health Expenditure) to get health services at the general health clinic of the health center for the ten main diseases of Rp. 1,096,620,000.

Table 1 Household expenditure in obtaining health services for 10 major diseases at Parepare District health center in 2017 


\begin{tabular}{|c|c|c|c|c|}
\hline No & The Type or Disease & $\begin{array}{l}\text { Number of } \\
\text { Visite }\end{array}$ & Transport to PKM & Percent $(\%)$ \\
\hline 1 & Upper respiratory tract infection & 25,727 & $90,044,500$ & 46.6 \\
\hline 2 & Essential Hypertension (Primary) & 10,952 & $38,332,000$ & 29.7 \\
\hline 3 & An unknown cause of fever & 10,367 & $36,284,500$ & 6.1 \\
\hline 4 & Normal pregnancy supervision & 7,785 & $27,247,500$ & 3.6 \\
\hline 5 & Gastritis & 6,666 & $23,331,000$ & 3.5 \\
\hline 6 & Headache & 5,223 & $18,280,500$ & 3.2 \\
\hline 7 & Cough & 5,208 & $18,228,000$ & 2.9 \\
\hline 8 & $\begin{array}{l}\text { Diarrhea and gastroenteritis } \\
\text { suspected of infectio }\end{array}$ & 4,564 & $15,974,000$ & 1.9 \\
\hline 9 & Dyspepsia & 4,313 & $15,095,500$ & 1.3 \\
\hline \multirow[t]{2}{*}{10} & Unspecified dermatitis & 3,728 & $13,048,000$ & 1.1 \\
\hline & Total & & $295,865,500$ & 100 \\
\hline
\end{tabular}

\subsection{Indirect Costs}

Indirect costs are costs that are lost because someone is suffering from a disease and cannot work productively and the number of costs lost because someone died before reaching life expectancy.

\section{Year of Living with Disability (YLD)}

A Year of Living with a Disability (YLD) is the number of years lost because a person cannot work productively due to illness. The number of years lost is divided into monetary value $(\mathrm{Rp})$.

Table 2 shows the number of years lost due to people suffering from large leprosy or the Year of Persistence with Disabilities (YLD) 1,0735.68 years, the number of YLD uses the Regional Minimum Wage of Rp. 27.000,000 per years per person for Parepare is Rp. $14.688,000,000$.

Table 2 Years of Lived with Disability (YLD) community in Parepare District in 2017

\begin{tabular}{ccccccc}
\hline No & $\begin{array}{c}\text { The Type of } \\
\text { Disease }\end{array}$ & $\begin{array}{c}\text { Number } \\
\text { of Visits }\end{array}$ & $\begin{array}{c}\text { Estimation } \\
\text { Of Product } \\
\text { Age Visits }\end{array}$ & $\begin{array}{c}\text { Estimation } \\
\text { of Disability } \\
\text { Days }\end{array}$ & $\begin{array}{c}\text { YLD (Th) } \\
\text { Loss (IDR) }\end{array}$ & $\begin{array}{c}\text { Percent } \\
(\%)\end{array}$ \\
\hline
\end{tabular}




\begin{tabular}{|c|c|c|c|c|c|c|c|}
\hline 1 & $\begin{array}{l}\text { Upper } \\
\text { respiratory tract } \\
\text { infection }\end{array}$ & 25,727 & 18.008 & 3 & 148 & $3,996,295,890$ & 27.19 \\
\hline 2 & $\begin{array}{l}\text { Essential } \\
\text { Hypertension } \\
\text { (Primary) }\end{array}$ & 10,952 & 7.666 & 4 & 84 & $2,268,295,890$ & 15.44 \\
\hline 3 & $\begin{array}{l}\text { An unknown } \\
\text { cause of fever }\end{array}$ & 10,367 & 7.256 & 3 & 59 & $1,610,235,616$ & 10.96 \\
\hline 4 & $\begin{array}{l}\text { Normal } \\
\text { pregnancy } \\
\text { supervision }\end{array}$ & 7,785 & 5.449 & 3 & 44 & $1,209,230,136$ & 8.23 \\
\hline 5 & Gastritis & 6,666 & 4.666 & 4 & 51 & $1,380,624,657$ & 9.4 \\
\hline 6 & Headache & 5,223 & 3.656 & 3 & 31 & $811,331,506$ & 5.52 \\
\hline 7 & Cough & 5,208 & 3.645 & 3 & 30 & $808,890,410$ & 5.5 \\
\hline 8 & $\begin{array}{l}\text { Diarrhea and } \\
\text { gastroenteritis } \\
\text { suspected of } \\
\text { infectio }\end{array}$ & 4,564 & 3.194 & 4 & 35 & $945,073,972$ & 6.43 \\
\hline 9 & Dyspepsia & 4,313 & 3.019 & 4 & 33 & $893,293,150$ & 06.08 \\
\hline 10 & $\begin{array}{l}\text { Unspecified } \\
\text { dermatitis }\end{array}$ & 3,728 & 2.609 & 4 & 29 & $771,978,082$ & 5.25 \\
\hline & Total & & & & 544.00 & $14.688 .000,00$ & 100,00 \\
\hline
\end{tabular}

\section{Years Life of Lost (YLL)}

Indirect costs due to mortality are costs that are lost due to someone passing away before reaching Life Expectancy. This fee is obtained from an approach based on the calculation of Years of Life Lost (YLL). The amount of indirect costs is described in table 3.

Table 3 Years of Life Lost (YLL) due to premature death before reaching life expectancy in Parepare District in 2017

\begin{tabular}{|c|c|c|c|c|c|}
\hline Dead Age & Amount & & YLL (Years) & Economic Loss (IDR) & Percent $(\%)$ \\
\hline $15-20$ & & 21 & $1,063.44$ & $2,871,288,000$ & 9.91 \\
\hline $21-25$ & & 18 & 911.52 & $2,461,104,000$ & 4.49 \\
\hline
\end{tabular}




\begin{tabular}{rrrrr}
$26-30$ & 12 & 607.68 & $1,640,736,000$ & 5.66 \\
$31-35$ & 15 & 759.60 & $2,050,920,000$ & 7.67 \\
$36-40$ & 17 & 860.88 & $2,324,376,000$ & 5.18 \\
$41-45$ & 24 & $1,215.36$ & $3,281,472,000$ & 11.32 \\
$46-50$ & 21 & $1,063.44$ & $2,871,288,000$ & 9.91 \\
$51-54$ & 35 & $1,772.40$ & $4,785,480,000$ & 16.51 \\
$55-60$ & 37 & $1,873.68$ & $5,058,936,000$ & 17.45 \\
$61-63$ & 12 & 607.68 & $1,640,736,000$ & 5.66 \\
Total & 212 & $10,735.68$ & $28,986,336,000$ & 100,00 \\
\hline
\end{tabular}

Table 3 shows the number of years lost for people in Parepare who died before reaching the life expectancy (YLL) of 10,735.68 years, with the economic losses caused by the mortality amounting to Rp.28,986,336,000.

\section{Total Economic Losses (Economic Lost)}

Parepare City Society Due to Morbidity and Mortality The total economic loss is the recapitulation of all expenses incurred by the HH-Exp, as well as the economic value of DALY which consists of the sum of YLD and YLL.

Table 4 Total Economic Lost communities in Parepare City in 2017

\begin{tabular}{|c|c|c|c|c|}
\hline No & Expense Type & Description & Amount & Percent $(\%)$ \\
\hline \multirow[t]{2}{*}{ A } & Direct Cost & & & \\
\hline & a. House Hold Expenditure & & & \\
\hline \multirow[t]{2}{*}{2} & Transport & Transport to PKM & $295,865,500$ & 0.67 \\
\hline & Total A (Direct Cost) & & $295,865,500$ & 0.67 \\
\hline $\mathrm{B}$ & Indirect Cost & & & \\
\hline 1 & Years Lived with Disability (YLD) & $\begin{array}{l}\text { Economic value of } \\
\text { YLD }\end{array}$ & $14,688,000,000$ & 33.4 \\
\hline \multirow[t]{3}{*}{2} & Years of Life Lost (YLL) & $\begin{array}{l}\text { Economic value of } \\
\text { YLL }\end{array}$ & $28,986,336,000$ & 65.92 \\
\hline & Total B (Inderect Cost) & & $43,674,336,000$ & 97.65 \\
\hline & Total Economic Lost (Total A+B) & & $43,970,201,500$ & 100.00 \\
\hline
\end{tabular}

Table 4 shows the total economic loss of the people of Parepare City due to morbidity and mortality of Rp.43,970,201,500, the losses caused by the people suffering from illness/disability with the economic value of YLD of Rp.14,688,000,000 (33.40\%), and the 
economic value of YLL amounting to Rp.28,986,336,000 (94.26\%), and HH-Exp Rp.295,865,500 (0.96\%).

\subsection{Increased Health Budget and Health Insurance through Advocacy}

To make efforts to prevent the emergence of large economic losses from the community, one of the efforts that can be done is changing people's behavior towards Clean and Healthy Life Behavior (PHBS and for people who need health checks and treatment, an effective, efficient and accountable financing system is needed through implementation of health insurance, so that when sick people are no longer charged with high health costs.

Table 5. Total Regional Budget (APBD) of the District Health and Health Insurance Office (JKN) of Parepare City 2012 - 2017

\begin{tabular}{|c|c|c|c|c|}
\hline \multirow[t]{2}{*}{ No } & \multirow{2}{*}{$\begin{array}{c}\text { Fiscal } \\
\text { Year }\end{array}$} & \multicolumn{2}{|c|}{$\begin{array}{l}\text { Regional Revenues and Expenditures } \\
\text { (APBD) }\end{array}$} & \multirow[t]{2}{*}{ Percent $(\%)$} \\
\hline & & District Health & $\mathrm{JKN}$ & \\
\hline 1 & 2012 & $32.576 .086 .966,00$ & $3.872 .812 .000,00$ & 11,89 \\
\hline 2 & 2013 & 34.164.579.439,00 & $5.316 .300 .450,00$ & 15,56 \\
\hline 3 & 2014 & $35.811 .433 .500,00$ & $3.762 .439 .400,00$ & 10,51 \\
\hline 4 & 2015 & 45.679.913.906,00 & $6.395 .187 .946,00$ & 14,00 \\
\hline 5 & 2016 & $143.407 .870 .868,00$ & 27.012.360.618,00 & 18,84 \\
\hline 6 & 2017 & $110.968 .501 .000,00$ & 26.937.009.788,00 & 24,27 \\
\hline
\end{tabular}

Table 5 the amount of the APBD allocation for health services in 2012 amounting to Rp.32,576,086,966.00 and in 2016 Rp.143,407,870,868.00, this significant increase was influenced by the results of advocacy to all of the main legislative stakeholders.

\section{Discussion}

Household expenditure of Rp. 295,865,500 to achieve PKM, the results of this research are the amount of urban transportation (auto) and motorcycle taxi, amounting to Rp. 5,000. So the amount of $\mathrm{HH}$ Exp obtained for transportation. In the City of Parepare, there is at least $1 \mathrm{PKM}$ located in the sub-district area, but some villages that are far from PKM still need transportation facilities to reach them. Patients use transportation because they are not strong enough to walk to PKM because of illness. The means of transportation used can be in the form of motorbikes or rickshaws (traditional transportation in the City of Parepare).

The results of research in several places indicate that one of the reasons for the low visit to the Puskesmas is due to the community's residence that is far from the puskesmas (low accessibility). This shows that even though they already have health care guarantees if they do 
not have the cost of transportation, they tend not to go to the health center. The same thing happened in Vietnam, namely to get health services, some people have to use transportation facilities [22].

If we look at the 10 most common diseases in the City of Parepare, some of them are preventable diseases, and diseases caused by unfavorable environmental conditions and the result of not implementing clean and healthy living behavior [23].

The results of the study showed that Essential Hypertension (Primary) disease had the second largest disease with YLD of IDR 2,268,295,890 (15.44\%). According to UNDP, this was caused by changes in lifestyle and increasingly shifting diseases caused by the environment and infectious diseases to degenerative diseases [24].

Economic losses experienced by the community that is derived from diseases that can be prevented as early as possible need comprehensive efforts from all stakeholders. So that in the following year YLL for the disease can be reduced in number.

This research proves that economic health is a huge investment for all of us who are sometimes overlooked. If the loss is Rp.28,986,336,000 can be prevented so that the economy in Parepare City can develop better, which is characterized by a healthy population and can work well. And economically if an intervention can reduce the loss, the cost of the intervention is investment [25].

Laura, et al's study (Global Burden of Disease Study) tract-level analysis of life expectancy and cause-specific census. These rates are important in health among neighborhoods in King County that are masked by county-level estimates. Efforts to improve population health in King County should focus on reducing geographical inequality by targeting those health conditions that contribute to the most to overall YLLs and inequality. This analysis should be replicated in other locations to more fully describe local-level variation in population health and contribute to efforts to improve health while reducing inequalities [26], [27].

Total Economic Lost) of Parepare which is an amount of Rp.43.970.201.500 or far greater than the Original Regional Income (PAD) in 2017. Yongwen Jiang's research in Rhode Islan in 2016 showed the highest risk for violent death. This study demonstrates the results of

advocacy carried out using the economic loss approach, the health budget in the city of Parepare has experienced a significant increase. Especially on the budget for the implementation of the National Health Insurance (JKN) [28], [29].

The Parepare City Government realizes that one of the responsibilities is to provide access to public services, and health services are services that are needed by the community. For this reason, the Health Service can be felt by all citizens.

As a follow-up to realize Health as a Strong Point of Development, the public health insurance manager conducts a study in advocacy for sharing parties, especially the legislature in implementing a health service and financing system, in regional health insurance.

\section{Conclusions}

Need to reduce economic losses due to illness (YLL) in the 10 biggest diseases in the City of Parepare, especially for degenerative diseases and symptoms, with the application of a clean and healthy lifestyle in the household environment. Because the data shows that most of the shifts in the pattern of causes of disease are unhealthy lifestyles.

The government is obliged to provide affordable and quality health services to every citizen by providing guarantees of access to health services in the form of youth reaching 
health services (transportation) and affordability in the form of guaranteeing the cost of health care through health insurance. The increase in the health insurance budget that is currently underway needed to be maintained and improved every year because the morbidity of the people of Parepare City is very high.

The need for efforts to prevent early death, especially in the productive age, some of whom die as a result of accidents, with the application of safety systems at workplaces and highways. Suppressing the death rate at a productive age is the biggest investment for the government of the City of Parepare.

Health advocacy is needed that can convince all strategic alliances that preventing losses due to illness and premature death is a large investment and will have an impact on the quality of life of the community. And one of the ways to advocate is through the economic loss approach

\section{References}

[1] International Burden of Disease.: Report Of The Foundation Meeting International Burden of Disease Network Atlanta Another reference. (1998)

[2] Maidin A.: Beban Ekonomi (Economic Burden) Masyarakat Akibat Sakit dan Kematian Dini di Kabupaten Tana Toraja Provinsi Sulawesi Selatan Program Pascasarjana Universitas Hasanuddin. Makassar. pp. hal. (2005)

[3] Murray C J L.: Rethinking DALYs. The global burden of disease. (Cambridge, MA: Harvard University Press). Pp.120-250 (1996)

[4] Kasman.: Survey Rumah Tangga Sehat di Kabupaten Polman Tahun 2009 Bagian Promosi Kesehatan Dinas Kesehatan Kabupaten Polman Provinsi Maluku Utara. (2006)

[5] Kasman M.: Efektifitas dan Efisiensi Pemanfaatan Dana Bantuan Operasional Kesehatan dengan Penerapan Metode Analytic Hierarchy Process. J. Kebijakan Kesehatan Indonesia. Vol. 1, pp.36 - 41. (2012)

[6] Gani A.: Dampak Krisis Ekonomi, Politik dan Sosial Budaya Terhadap Kesehatan. SeminarLokakarya Krisis Kesehatan di Indonesia Depkes RI Lembang.pp.1-7 (2000)

[7] Kasman M A.: Model Penetapan Tarif Rasional Berdasarkan Relative Value Unit dan Cost Recovery Rate Unit Bedah Rumah Sakit di Sulawesi Selatan. Program Pascasarjana Universitas Hasanuddin Makassar. pp. 23-40. (2004)

[8] Mehrnoosh A .: Deaths DALY and other related measures of breast cancer in Yemeni women: Findings of the Global Burden of Disease Study (1990-2010). Vol. 167, pp 372-385. (20180

[9] Mills A dan Luci G.: Ekonomi Kesehatan untuk Negara-begara Sedang Berkembang. Dian Rakyat Jakarta. (1990)

[10] Christopher J L M, Theo V. : Disability-adjusted life years (DALYs) for 291 diseases and injuries in 21 regions, 1990-2010. A systematic analysis for the Global Burden of Disease Study 2010. Report Global Burden Deseases.pp.2197-2223 (2013)

[11] Amen A B.: Deaths DALY and other related measures of breast cancer in Yemeni women: Findings of the Global Burden of Disease Study. J. of Cancer Research and Practice. Vol. 4, pp. 14-18. (2017)

[12] Disease and Injury Incidence and Prevalence Collaborators.: Global, regional, and national incidence, prevalence, and years lived with disability for 328 diseases and injuries for 195 countries. A systematic analysis for the Global Burden of Disease Study 2016. Vol. 390, pp. 1211-59. (2017)

[13] Franco S.: Calculating QALYs comparing QALY and DALY calculations. Oxford University Press in association with The London School of Hygiene and Tropical Medicine. pp 402-408. (2006)

[14] Arnesen T, Nord E.: The Value of DALY Life. Problems With Ethis and Validity of Disability Adjusted Life Years, BMJ. Vol.319.pp1423-1425 (1999)

[15] Ariel C, Kathryn H J, Ashish A. D, Scott B. C.: DAge-sex specific and sequela-specific 
disability-adjusted life years (DALYs) due to dental caries preventable through water fluoridation: An assessment at the national and subnational levels in Iran, 2016. SocioEconomic Planning Sciences. Vol. 49, pp.10-15. (2018)

[16] Ariel C, Kathryn H J, Ashish A D, Scott B C.: The evolution of the disability adjusted life year (DALY). Socio-Economic Planning Sciences. Vol. 49, pp. 10-15. (2015)

[17] Tati S.: Beban Penyakit (DALYs LoSS) di Indonesia dan Prediksi Wilayah Kepulauan Semiringkai Nusa Tenggara Timur, Buletin Penelitian Sistem Kesehatan. Vol. 19, pp. 127134. (2016)

[18] Tingting G, Xiaochang C W, Rong C, Huu H N, Wenshan G.: Disability adjusted life year (DALY). A useful tool for quantitative assessment of environmental pollution, Science of the Total Environment. Vol.511. pp. 268-287. (2015)

[19] Susi A K, Dwi E, Natalia S, Octy P.: Estimating the Burden of Cancers Attributable to Smoking Using Disability Adjusted Life Years in Indonesia. Asian Pacific J. of Cancer Prevention. Vol. 17, pp. 1577-1581. (2016)

[20] Jun Y, Chun-Quan O, Yu-Feng S, Li Li, Ping-Yan C, Qi-Yong L.: Estimating years of life lost from cardiovascular mortality related to air pollution in Guangzhou, China, Science of the Total Environment.Vol.573.pp. 1566-1572 (2016)

[21] GBD 2013 DALYs and HALE Collaborators.: Global, regional, and national disability-adjusted life years (DALYs) for 306 diseases and injuries and healthy life expectancy (HALE) for 188 countries, 1990-2013. Quantifying the epidemiological transition Lancet. Vol.386. pp. 2145-2191.(2015)

[22] Trinh M H.: The Estimates of the Health and Economic Burden of Dengue in Vietnam, Trends in Parasitology. Vol. 34, pp. (2018)

[23] Mboi, Indra M S .: On the road to universal health care in Indonesia, 1990-2016. A systematic analysis for the Global Burden of Disease Study, 2016 Lancet. Vol. 392, pp. 581-59. (2018)

[24] United Nation Development Programe.: Human Development Report 2010 (New York: UNDP).pp.1-86 (2010)

[25] Qiang Z, Ziting W, Guohong J, Pei L, Yang N, Guoxing L, Xiaochuan P.: The association between inhalable particulate matter and YLL caused by COPD in a typical city in northern China Atmospheric Environment. Vol. 26-31.pp. 26-3.( 2017)

[26] Laura D-L, Rebecca W S, .: Variation in life expectancy and mortality by cause among neighbourhoods in King County, WA, USA, 1990-2014. A census tract-level analysis for the Global Burden of Disease Study 2015 Lancet Public Health. Vol. 2, pp.400-10. (2017)

[27] Yongwen J, Megan L R, MD, Beatriz P, Samara V-B.: Burden of Violent Death on Years of Life Lost in Rhode Island 2006-201 American J. of Preventive Medicine. Vol. 51, pp. 251259.(2016)

[28] Amran R.: Kesehatan Gratis Sebagai Komoditi Politik. Suatu Tinjauan Prospektif Pembiayaan Kesehatan. J. Madani FKM UMI. Jilid 2 Terbitan 2. pp 67-78. (2008)

[29] Sidin, A. I., Mangilep, A. U. A. and Dewiyanti, S.: Can The Length of Nurse Employment Lead to Work-related Stress at Inpatient Ward in Hasanuddin University Hospital , A Teaching Hospital , Makassar , Indonesia'. Indian Journal of Public Health Research \&Development. Vol. 9, pp. (2018) 